\title{
Globalization of Culture and the Arts
}

\author{
Laura L. Adams* \\ Harvard University
}

\section{Abstract}

This article examines the state of the field in the sociological literature on the globalization of culture and focuses on key empirical works in the globalization of the arts. The first part of the article presents the main trends in theorizing about the globalization of culture in its broadest terms, that is, the large-scale changes in worldviews that both facilitate and are made possible by globalization such as modernization, universalism, consumerism, and McDonaldization. The second part of the article examines empirical work on television, music, and the performing arts in light of theorizing about globalization and commodification, audience reception, localization and glocalization, the role of the state, imperialism, global cultural fields, and global norms. In terms of theory, the article explores the tension between globalization's homogenizing and diversifying tendencies. The review of the empirical literature includes research conducted in Cuba, Israel, Italy, Japan, Russia, Singapore, the USA, and Uzbekistan.

\section{Introduction}

One of the basic questions about globalization is whether the contemporary phenomenon of increased interconnectedness among various parts of the world is anything new. Is not the whole of human history a story of the expansion of human populations across the globe, populations that often remained connected by cultural and economic ties? Or is globalization something different, a phenomenon of the modern era brought on by rapid changes in telecommunications and transportation technologies? From the perspective of cultural globalization, there is no easy answer to these questions because in essence, modern telecommunication and transportation have been used to speed up what had already been taking place. In this sense, globalization is a continuous human process not limited to a specific historical period.

However, in another sense the globalization of culture as we know it today is a qualitatively different phenomenon with worldviews and assumptions about the nature of culture and humanity that differ from those of previous eras. In the contemporary era, as Anthony Giddens 
and Roland Robertson have argued, globalization is about an increase in reflexivity (self-awareness) in addition to economic and technological changes (Giddens 1990; Robertson 1992, 32-3). Reflexivity transforms our understandings of ourselves in relation to our global 'significant others'. Robertson suggests that during the twentieth century, culture (those sets of values and practices shared by a particular community) came to be understood through a universal matrix: all cultures were similarly unique, all groups had something that they (and others) could label 'their' culture when seen through this universal matrix of culture. This 'universalization of particularism' is intertwined with the 'particularization of universalism', the idea that there can be such a thing as values and commonalities that all humanity shares. Particular groups across the world have come to entertain the idea that all human communities perhaps have certain things in common, and that such commonality allows for the translation of so-called universal ideas (such as human rights or World Bank economic theories) to any particular context (Robertson 1997).

Most sociologists also see globalization as a quantitative change in social processes that are not new in and of themselves, but are new in terms of the scale on which they take place. David Held and his colleagues have usefully broken down globalization into scalar dimensions such as the extent of global networks, the intensity of global interconnectedness, the velocity of global flows, and organizational dimensions relating to global infrastructure and institutions (Held et al. 1999). So the formation of group identity in relation to a 'significant other' now takes place not just on a community level (as in the case of a neighborhood with different ethnic or religious groups), or between subaltern groups and their imperial center (as in the case of Armenians in relation to Turkey or Russia, for example), but on a truly global scale, with high velocity flows facilitated by high-tech infrastructure and international norms.

Similarly, the process of cultural exchange and adaptation of beliefs and practices takes place at a much faster rate than previously, and the menu of cultural options to choose from in most locales around the world has greatly increased, so that most people can listen not just to indigenous folk or sacred music, but rock, rap, and European classical music, as well, on a daily basis. This expansion of options and acceleration of cultural change is at the heart of most of the scholarly debates about globalization's homogenizing tendencies. Held et al. (1999) characterize the debate in terms of three main tendencies: the perspective that globalization is an acceleration of already existing trends fueled by the dynamics of modernity is representative of the transformationalist point of view; skeptics, on the other hand, see globalization simply as another phase of the era of the nation-state; and hyperglobalists see globalization as an entirely new era where the power of the nation-state has been eroded by global capital leading to a truly global society. 
Transformationalists emphasize that globalization both homogenizes and differentiates culture, as well as engendering a variety of syncretic processes such as hybridization, cosmopolitanism (a taste for the culture of the 'other', an interest and participation in cultures not one's own, see Hannerz 1990), glocalization (the top-down adaptation of business and other practices to local cultural conditions, see Robertson 1995), and indigenization (the creative, bottom-up adaptation of more generalized practices to the local context). Some even argue that these global systems are constructing a global culture that does all of these things at once. Smith, for example, presents a relatively rosy scenario of a global culture that "would operate at several levels simultaneously: as a cornucopia of standardized commodities, as a patchwork of denationalized ethnic or folk motifs, as a series of generalized "human values and interests", as a uniform "scientific" discourse of meaning, and finally as the interdependent system of communications which forms the material base for all the other components and levels' (1990, 176).

These processes are seen by many transformationalists as taking place within a larger system of cultural flows that is shaped by the dynamics of global systems, such as capitalism and imperialism (Appadurai 1996; Tomlinson 1991, 1999). Rather than as seeing cultures as bounded by societies, Arjun Appadurai points out that economies, cultures, and polities do not fit neatly together and encourages us to think instead in terms of 'scapes', as in a flowing and irregular landscape framed by a particular point of view (e.g., 'what does the ethnoscape look like from here?'). He highlights five main scapes (ethnoscapes, mediascapes, technoscapes, financescapes, and ideoscapes) and argues that social scientists need to study the ways that global flows take place through the interstices of these scapes (Appadurai 1996, 32-3).

While many sociologists and anthropologists have embraced the transformationalist scenario, not everyone is so sanguine about the adaptability of local cultures. Some who fall into the skeptic camp fear a backlash against globalization that would lead people to cling ever more tightly to their particularism. A number of scholars, many of them political scientists, have expressed a concern over a backlash against Americanization, Westernization, and the globalization of culture that might eventually produce violent conflict (Barber 1996; Huntington 1993). In this scenario, the economic and cultural domination of the West combines with the reflexivity of modernity to provoke nonWestern communities to become more aware of their own culture, from which they are becoming alienated by the forces of globalization, but which at the same time composes the most basic and immutable part of their identities. The globalization of culture thus becomes a painful paradox, whereby the value and awareness of one's own culture becomes more important, namely, because it is being destroyed. Thus, the 
universalism of modernity and the integrating forces of global capitalism combine to ironically propagate differentiation.

Hyperglobalist critics of global capitalism fear a scenario of cultural domination based on the interests of the 'transnational capitalist class', which promotes a homogenizing 'culture-ideology of consumerism' (Sklair 1995). Leslie Sklair sees the driving force behind the globalization of culture as being rooted in global capitalism's project to 'persuade people to consume above their own perceived needs in order to perpetuate the accumulation of capital for private profit ... The culture-ideology of consumerism proclaims, literally, that the meaning of life is to be found in the things that we possess' $(1995,48)$.

The culture-ideology of consumerism, like Robertson's universalismparticularism dynamic, embodies what Sklair calls first order meanings (underlying assumptions and hegemonic worldviews) that provide the ideological background against which changes in second order meanings (those produced in particular contexts through the wearing of Western clothing, the playing of rock music, and the eating of sushi, for example) take place. Another first order homogenizing tendency, which bears certain resemblances to both Sklair's consumerism and Giddens' theory of modernity, is George Ritzer's McDonaldization, which is grounded in the spread of an ideology of Western capitalist rationality. According to Ritzer, the fast food restaurant model of consumerism is coming to dominate ever more sectors of society, resulting in the spread of a standardized set of practices that emphasize efficiency, predictability, calculability, and control. Ritzer, a pessimistic romantic, sees globalization as a process of the proliferation of 'nothing', that is, the increasing dominance of a culture that is devoid of distinctive content, spread by imperialistic nations, corporations, and organizations (2007).

Now that we have reviewed some explanations of the underlying explanations of how globalization promotes both cultural homogenization and differentiation, the rest of this article will examine specific examples of 'second order' phenomena in order to explore the depth and complexity of local cultural changes in response to globalization. While anthropologists often spend a lot of time 'on the ground' observing interactions in real time, sociologists studying the globalization of culture tend to focus on those areas of culture about which data is easy to collect. This leads to three biases in what is explored in the empirical literature: a bias towards commercial culture produced by multinational corporations whose sales figures are often publicly available; a bias towards recorded cultures whether or not they are produced for commercial markets, due to the relative permanence and transportability of books, video tapes, compact discs and so on; and a bias towards studies of state policies, at both the national and international government levels, because of the easy access researchers have to official records and 
statistics. All three of these biases lead us to see globalization as being a predominantly homogenizing force, due to the way that corporations try to ensure uniformity and predictability, the way that recordings fix culture in time, and the way that international organizations and national governments promote standardization.

The rest of this article will explore some of the empirical work done on globalization of culture and the arts. The research showcased here was chosen with an eye to questions of commercialization, reproducibility, and state policies, and along the way draws our attention to an eclectic group of countries (Cuba, Israel, Italy, Japan, Russia, Singapore, the USA, and Uzbekistan) with differing levels of economic globalization and state involvement in culture production. The examples of cultural globalization in this article progress from the highly commercialized culture of television and film, to forms of culture (rock and rap music) that can be found both in commodified and noncommercial forms (such as amateur or subsidized performances), and concluding by looking at performing arts genres that are not easily commodified (opera and theater). When we focus on the performing arts, it is easier to avoid the first two kinds of bias, though often the state's role is highlighted. In part, this emphasis on the state is not a result of bias towards easy to collect data, but is precisely because culture that is not recorded and distributed by multinational corporations often relies on state support for its very existence. After all, recorded and mass-marketed culture is not only easier for researchers to study, it is easier (and often cheaper) for consumers to consume.

\section{Recorded cultures: Television and the adaptation of visual culture}

When a journalist wants to criticize globalization, he or she will most often include an anecdote about the consumption of either McDonald's or American television in some seemingly exotic locale. Indeed, North American television programs and Hollywood movies are often taken for the harbingers of cultural catastrophe in other parts of the world, the vanguard of the culture-ideology of consumerism, and the instrument of American cultural imperialism. Television programs and films from the USA often use their origin and the symbols of the American way of life as part of their marketing strategy, and because the USA produces such a large share of the mass media products available in the world, the globalization of culture is often cast as simple Americanization. However, empirical studies of the consumption of television and film question the assumptions behind this Americanization thesis. Sociologists generally agree that a simplistic view of cultural imperialism does not adequately explain the relations of domination and resistance between colonial peripheries and their imperial centers, let alone between cultural 
centers such as Hollywood and the peripheries that consume its cultural products (Tomlinson 1991).

Even critics such as Sklair are clear in arguing that the transnational capitalist class is not an American capitalist class, nor is the culture promoted by the culture-ideology of consumerism American culture. Ritzer and other sociologists also argue that it is important to delineate consumerism and mass media from Americanization per se (Ritzer and Stillman 2003). America's economic influence has led to the spread of consumerism and mass media, to be sure, but the way that these processes are articulated in cultural terms is often just the expansion of a local language vocabulary. So, for example, Americanization 'led to the intensified proliferation of popular consumer cultures specific to Japan manga (comics), pachinko (pinball games), karaoke - but did not create these cultural practices ... [and other practices involve] the consumption of Western themes but in a very non-Western manner and according to conventionalized patterns of behavior' (Delanty 2003, 119). That is, globalization relates to the expansion of the symbolic repertoire of a particular group (e.g., having birthday parties at McDonald's instead of a regular restaurant as a sign of high status), but the symbolism itself derives its meaning from local cultural norms and understandings (e.g., what is the significance of birthday parties? who gains status from McDonald's vs. another venue?).

Empirical studies of the consumption of television and film not only question the assumptions behind the Americanization thesis, they also show a diversity of practices and interpretations employed by local consumers. The study of the reception and production of cultural meanings is essential to avoid examining globalization from a purely outside perspective. What looks like hybridization to us may look very different from the perspectives of the producers and consumers of culture themselves. As Jonathan Friedman argues, studies that do not attempt to understand the local production of meaning lack objectivity and become 'our own subjective interpretation of our objectification of other people's lives' (2006, 404). A classic study of globalization and the reception of television is Liebes and Katz's The Export of Meaning: Cross-Cultural Readings of 'Dallas' (1993). Liebes and Katz conducted focus groups with ethnically homogenous groups of Israelis (representing very different cultural backgrounds), Americans in Los Angeles, and Japanese in Japan in order to see how different audiences differently 'decoded' meanings in the same cultural product. Liebes and Katz found that the culturally more traditional groups primarily used their discussion of the program to relate back to their own lives and interpreted the problems of the Ewing dynasty through the framework of their own culture, using the discussion as an opportunity to critique the values portrayed and reaffirm their own culture's values. Other groups used their discussion to engage in a sometimes playful, 
sometimes serious critique of the show's ideological subtext and its aesthetic value (or lack thereof). Thus, even when consumers are being drawn into the American cultural sphere through the exportation of television programs, Liebes and Katz suggest that the interest in these programs comes in part from 'the polyvalent or open potential of many of the stories, and thus their value as projective mechanisms and as material for negotiation and play', which allow for 'guessing games, ludic fantasies, self-reflection, moral outrage, critical disdain, and more' (1993, 4-5).

A more recent study of the global television industry shows the ways that programs made for the US market are adapted abroad (Bielby and Harrington 2002). The most common adaptation is simply dubbing a television show into the local language, but even then, a local flavor is often given to the dubbing. For example, 'The Nanny' was shown in Italy complete with an imitation of Fran Drescher's annoying voice, but the Nanny character herself, instead of being Jewish as she was in the US version, was Sicilian and the actress dubbing her voice spoke in a Sicilian dialect. A much more extreme adaptation through dubbing can be seen in the various unofficial (but popular) versions of The Lord of the Rings movies dubbed into Russian by Goblin (the pseudonym of Dmitry Puchkov). The movies, adapted by New Zealanders from the novel by an Englishman, filmed largely in New Zealand with backing by Hollywood, are dubbed by Goblin in ways that take considerable liberty not just with the ethnic valences given to the various characters (Gimli the Dwarf, for example, is dubbed with a Georgian accent), but also with the plot itself, casting the entire epic as a Russian gangster film where Gandalf quotes Karl Marx, Fyodor (Frodo) speaks in a criminal dialect, and some of the soundtrack is replaced with Russian pop music.

Another form of adaptation is through the creation of original local content, sometimes through a foreign licensing agreement where the 'frame' of the show is known as American, such as MTV, but also increasingly through local versions of programs that have been successful in another country's market (Bielby and Harrington 2002). This can be seen in the USA with US versions of programs such as The Office from British television, Ugly Betty from Columbia (which was actually adapted for Russian television before it made it to the $\mathrm{ABC}$ network in the USA), and Iron Chef from Japan. These 'glocalized' programs tend to add some local spin on the original premise in order to make it indistinguishable from a local product, and indeed, often viewers are not aware that the show they are watching is a version of a concept originally developed elsewhere. This strategy of removing what Koichi Iwabuchi has called the 'cultural odor' of a particular product has been especially successful as employed in the exportation of Japanese popular culture in Asia (Iwabuchi 2002). 
A much broader kind of adaptation is the spread of a particular genre of program (such as the sitcom or reality television). An example of this was the way the US 'soap opera' became globalized via the Latin American 'telanovela' genre. It was primarily Mexican and South American 'telanovelas' that permeated the global television market and now countries around the world are producing their own melodramatic serials based not on a US standard but on what they have seen from Latin American television, first dubbed into their own languages, and then completely adapted in original productions that cater to the local culture. Having one's own 'teleserial' in a country such as Uzbekistan is not just a way of more broadly appealing to local tastes, it is also an indication (via the universal matrix of culture) of equivalence with other countries and a symbol of national belonging in a globalized cultural community. But it is not just the case that it is the 'locals' who are doing all the adaptation. The head writer for The Bold and the Beautiful (the most popular US soap opera in the world), said 'I am definitely aware of our international audience when I develop storylines', focusing more on romance, for example, than on courtroom sagas (as quoted in Bielby and Harrington 2002, 222). The research on television, often taken as one of the clearest indicators of American cultural imperialism, instead supports Arjun Appadurai's assertion that 'the United States is no longer the puppeteer of a world system of images but is only one node of a complex transnational construction of imaginary landscapes' (Appadurai 1996, 31).

\section{World music, rock and rap}

Music occupies an intermediate position in this article's schema of high to low levels of commercialization and reproducibility, with examples of both recorded and performed culture. When one thinks of the globalization of music, one probably first thinks of the growing genre of 'world music', which highlights not just the increased global circulation of local musical genres and styles, but the increasing cooperation between local artists, internationally popular musicians, multinational recording companies, governments, and international organizations. Martin Stokes, for example, relates a 'world music' story about how an ethnographic CD, released in France, of recordings of aboriginal Taiwanese musicians on a European tour promoted and funded by the Taiwanese and French governments, eventually wound up being sampled by a Romanian-German musician for his band Enigma. The result was a popular dance CD that sold 5 million copies, and that had a track that was licensed as one of the official songs for the Atlanta Olympics, and was thus used by television networks such as CNN and NBC to promote their Olympics coverage (Stokes 2004). Here we have what seems to be a perfect illustration of how global cultural flows 
move between centers and peripheries, create hybrid popular cultures that appeal to cosmopolitan tastes, and eventually feed into commercial markets dominated by multinational corporations.

However, we may be tempted back to the Americanization thesis when we look at other ways that the globalization of music shows up. After all, the most popular musical genres in the world, rock and rap, have American roots. When we look closer though, we find a challenge to the imperialism thesis (if not to the culture-ideology of consumerism, in as much as rock and rap music are highly commodified) that comes from these genres being associated not just with their American roots, but their roots in the African-American subculture and in urban youth culture. Motti Regev argues, for example, that rock music is actually seen by its producers as a universal (rather than Americanizing) cultural form, because it is not associated with the dominant values of US culture, that is, because of its subversive nature.

The rock aesthetic was accepted by musicians and audiences around the world as a way - as the way for some of them - to make local music that expressed rebellion against conservative traditional cultures and authoritarian regimes. Local hybrids of rock music often came to be perceived as authentic expressions of a modern and contemporary spirit within local or national cultures. (Regev 2003, 226)

As a result of this shared aesthetic and the institutions that accompany it, Regev (1997) argues that there is a global field of rock music production, in which musicians in different countries all refer to a common status hierarchy and where cultural forms operate with certain consistent effects in a global field of culture production. We will return to the importance of global cultural fields in the following section.

Similar forces can be seen at work in the globalization of hip-hop. Like Liebes and Katz's study of Dallas, Richard Kaplan calls our attention to the differences between the production and reception of culture by showing how an originally vernacular culture can be adapted to serve local purposes in an entirely different part of the world. His study of the representation of African-Americans and the reproduction of 'blackness' in Italy through the consumption of hip-hop culture demonstrates 'the audience's active role in producing cultural meanings as it receives media messages, and also ... the mediation of local industries, which introduce their own selections, emphases, and biases' (Kaplan 2002, 200). Rap in Italy is a " useful discourse"; it is a multiply accented, expansive vernacular that can be molded to the agendas and experiences of diverse individuals and social groups' in part because, like rock music, this vernacular carries with it a diverse range of perspectives and the expectation of social critique (Kaplan 2002, 203). The globalized consumption of music demonstrates the weakness in the assumption that consumerism and globalization necessarily equate 
to cultural homogenization by showing, as Friedman says, that consumption is 'an aspect of broader cultural strategies of self-definition and self-maintenance' $(1990,312)$. However, it still leaves open the question that Sklair raises of whether any of this rebellion does anything to subvert the hegemony of the culture-ideology of consumerism, in as much as 'ordinary so-called counter-cultures are regularly incorporated and commercialized and pose no threat, indeed through the process of differentiation (illusory variety and choice), are a source of great strength to the global capitalist system' (Sklair 1995, 48).

Therefore, we must also look at the less commodified side of globalized music and examine local strategies that, in some cases, explicitly reject the culture-ideology of consumerism. In Cuba, for example, 'images of rebellion and resistance in Cuban rap are drawn into broader geopolitical strategies of black cultural opposition; these are identified with the Cuban revolution and by extension the Cuban government as the lone voice contesting neoliberalism in a largely capitalist world order' (Fernandes 2006, 121). Sujatha Fernandes shows that the introduction of rap music into Cuba, as in many parts of the world, subverted the intended purpose of recorded culture as a commodity by being incorporated in small-scale, local contexts (at parties, on the street, in parks) in the form of circulated CDs of US artists, recordings from Miami radio stations, and informally duplicated cassette tapes (Fernandes 2006). Eventually, the multinational recording industry began to play a significant role in the development of Cuban hip-hop, and successful groups, such as Orishas, used recording contracts as a way to live and work outside the country. However, this participation in commercial music reflects a split in the Cuban hip-hop world between commercial and underground music that shows how the globalization of culture can have very different effects depending on context. On the one hand, Cuba's commercial hip-hop artists tune into ways to be more broadly popular by mixing with salsa and other more recognized genres and drawing on prerevolutionary stereotypes about rum, tobacco, and dancing in the streets. On the other hand, underground musicians avoid such fusion, have a more radical political stance, and are associated with transnational activist networks rather than corporations. The socialist state, in turn, financially supports groups who criticize capitalist values. As the next section will show, state support for the arts can have very different interactions with globalization processes depending on the state's political orientation, economic position, and historical legacies.

\section{Performance cultures: Opera and theater as state- subsidized art}

The heading of this subsection is likely to be misleading, in as much as the word 'opera' will probably be read by most people as referring 
to the European cultural genre exemplified by Verdi and Wagner. But here the term refers to Chinese opera as performed in Singapore, which Terence Chong uses as a case study to show that 'the complex relationship between ethnic identity and cultural power [is] mediated by global flows and pressures within a national sphere,' and how the changing meanings of Chinese identity appeals 'to the global or the imaginary homeland to win legitimacy in the national sphere' (Chong 2006, 284-5). Singapore has a strong corporatist state that took an active interest in using culture policy to express its global orientation and economic goals in the late 1980s through its 'Global City for the Arts' campaign that encouraged art forms that would appeal to global audiences, especially tourists and Singapore's cosmopolitan middle class. In contrast to the government of Cuba, which supported underground rap because of its anticapitalist and egalitarian messages, the biases of the Singaporean government reflect colonial legacies and the global prestige of English language culture, replicating the inequalities and disparities of globalization (Chong 2005).

However, in spite of its vernacular status, Chinese opera, which was fading into obscurity in the 1960s and 1970s, experienced a revival in the 1980s due to government concerns about the 'deculturalization' of the Chinese population, namely, the adoption of the Western values of individualism, hedonism, and liberalism. Here, we see an interesting parallel to the case of rap music in Cuba, with the Singaporean government attempting to legitimize Chinese identity through art, through the promotion of what had formerly been a 'street' art form to a 'high' art form. As in Cuba, this bias benefited amateur troupes, who were seen by the government as artistic, urban, and literate, whose 'authenticity' appealed to the state's construction of ethnic high culture and whose financial dependence on the state made them more open to the government's goals. With the rise of the Asian economies, the government of Singapore implemented policies to raise the local value of Chinese cultural capital and to tap into a broader ideology that saw Confucian cultures as the basis for a non-Western, universal culture that could serve as the seed of a new global culture. Chong concludes that the case of Chinese opera in Singapore shows how globalization can foster diversity as long as "ethnic cultures and notions of "heritage" continue to be useful in the political struggles for recognition of power ... [thus making it] highly unlikely that cultural homogenization will be globalization's only outcome' (Chong 2006, 303). In a bid to legitimate a local culture as universal culture, states end up promoting (and transforming) vernacular forms of culture in part because they are so different from competing versions of universal culture.

The theater that will be discussed here is European-style theater in Soviet and post-Soviet Uzbekistan, where the Russian and Soviet 
colonial experience created hierarchies of knowledge and values among culture producers in Uzbekistan that both privileged European culture and created a space for the universalization of Uzbek national culture through the participation in global cultural forms (Adams 2005). During the Soviet era, the state actively developed Europeanstyle theater in Uzbekistan in both the Russian and Uzbek languages. But even after becoming independent in 1991, elites in Uzbekistan continued to be interested in promoting European cultural forms. Adams argues that global cultural forms, such as theater, retain their place in contemporary Uzbekistan, because they serve as a means of communication with an often imagined, and sometimes real, audience beyond their local communities (Adams forthcoming). While certain imported cultural forms, such as theater, have been indigenized and are seen as 'ours' by Uzbeks, others forms that are associated with cultural imperialism, such as (European) opera and ballet, are retained mainly as markers of global prestige - not 'ours' but something these elites perceive that they need in order to demonstrate that they are a modern, civilized nation.

As with Regev's study of rock music, these studies of the performing arts draw on Bourdieu's concept of fields (Bourdieu and Johnson 1993) to explain how cultural flows are structured within and across national boundaries, and to show how 'the local transcends the national to tap into the global for legitimacy' (Chong 2006, 300). Bourdieu's metaphor is derived from sports, where play is governed by rules that apply to everyone, but some of the players have skills or knowledge (capital) that allow them to gain a more advantageous position on the playing field. Players thus compete with each other for a better position for their particular forms of capital, as in the case where jazz went from low-status music in the USA, to high culture in the USA, to global idiom. Expanding Bourdieu's metaphor, scholars have begun to see cultural fields as operating at multiple levels, both locally and globally. In Uzbekistan, for example, global cultural forms such as Europeanstyle theater operate as means of exchange that translate prestige across various levels of cultural fields. Culture producers choose global forms because they want to communicate the particularity and uniqueness of their national or local culture through a universal medium that makes their culture intelligible to their international peers. So while global cultural forms allow communication to take place between geographically distant cultural elites, a theory of global cultural fields helps to explain why such communication is desirable in the first place. Adams argues that it was not capitalist globalization but the Soviet socialist state's rapid modernization of Central Asia and its ideological and material commitment to internationalism that opened an emerging global cultural field to Central Asian culture producers. The global field provided new rules for the game of culture production 
through both the direct participation of artists in the global cultural field and the imagination of the global arena when producing culture back on the home field (Adams forthcoming).

Like Fernandes' research on Cuba, these studies examine how the performing arts are used to craft definitions of both particular and universal identities in cooperation with the national state. As Diana Crane and her colleagues argue, elites institutionally located in government and other large organizations employ a variety of 'cultural policy strategies' to both shore up local culture production in the face of globalization and stake a claim to the local culture's role in global culture (2002). In this institutionalist view, "cultural globalization is a process that involves competition and negotiation as organizations and countries attempt to preserve, position, or project their cultures in global space' (Crane 2002). The institutionalist approach taken by John Meyer and his colleagues also provides a framework for understanding the importance of global norms in shaping state policies and elite understandings of what is 'normal', 'modern', or 'civilized' culture (Boli and Lechner 2005, Meyer et al. 1997). In the case of Singapore, for example, globally oriented cultural policy emphasizes the role of the arts in propagandizing desirable values and national identity, as well as 'the government's desire to be seen as abiding by international norms. For example, the city-state's authoritarian and austere reputation has made it difficult to shake off its international image as a "Disneyland with the death penalty" (Chong 2005, 557). In the Soviet case, the state served as an important channel for the adoption of internationally legitimated cultural forms, giving post-Soviet states readymade links to the global community. These links have played an important role in defining post-Soviet identities by giving culture producers a frame of reference for what their national culture should look like (Adams 2005).

\section{Conclusion}

Looking back on the first order changes in culture that this article started with, what do these second order phenomena tell us about the depth and complexity of local cultural changes in response to the dynamics of universalism-particularism and its backlash, or McDonaldization and the culture-ideology of consumerism? The empirical research on the globalization of culture and the arts lends clear support to the importance of modernity's reflexivity and universalism in creating common first order understandings of culture and human values, while failing to demonstrate a significant backlash against global culture, Americanization, or cultural imperialism that is not also incorporated into broader global discourses of human rights and the importance of cultural preservation. That is, even antiglobalization movements tend 
not to focus solely on speaking to the local community in local terms, but play up the contradictions inherent in globalization's homogenizing tendencies (such as its universalization of particularism) in order to appeal to broader constituencies' concern over the common dilemmas faced by the unique cultures that are being overwhelmed. Similarly, the effect of routinized, homogenized culture predicted by the McDonaldization thesis is less powerful than the ability of local cultures to make meanings out of seeming empty or deterministic forms. At the same time, it is clear that the hegemony of consumerism is all but complete except in rare cases where organizations and states provide material support for cultural content and practices that reject the ideology of capitalism and the commodification of culture.

\section{Short Biography}

Laura Adams' research explores the interactions between globalization and the nation-state in the context of the visual and performing arts, specifically in Soviet and post-Soviet Central Asia. Currently she is teaching in the Expository Writing Program of Harvard University and is an associate at the Davis Center for Russian and Eurasian Studies. Laura received her BA in sociology and Russian area studies from Macalester College (USA) and her PhD in sociology from the University of California, Berkeley.

\section{Note}

* Correspondence address: Harvard University, 8 Prescott St., Cambridge, MA 02138, USA. Email: lladams2@earthlink.net.

\section{References}

Adams, Laura L. 2005. 'Modernity, Postcolonialism and Theatrical Form in Uzbekistan.' Slavic Review 64: 333-54.

Adams, Laura L. forthcoming. 'Globalization, Universalism and Cultural Form.' Comparative Studies in Society and History.

Appadurai, Arjun 1996. Modernity at Large: Cultural Dimensions of Globalization. Minneapolis, MN: University of Minnesota Press.

Barber, Benjamin R. 1996. Jihad vs. McWorld. New York, NY: Ballantine Books.

Bielby, Denise D. and C. Lee Harrington 2002. 'Markets and Meanings: The Global Syndication of Television Programming.' Pp. 215-32 in Global Culture: Meida, Arts, Policy, and Globalization, edited by Diana Crane, Nobuko Kawashima and Ken'ichi Kawasaki. New York, NY: Routledge.

Boli, John and Frank Lechner 2005. World Culture: Origins and Consequences. Malden, MA: Blackwell.

Bourdieu, Pierre and Randal Johnson 1993. The Field of Cultural Production: Essays on Art and Literature. New York, NY: Columbia University Press.

Chong, Terence 2005. 'From Global to Local: Singapore's Cultural Policy and Its Consequences.' Critical Asian Studies 37: 553-68. 
Chong, Terence 2006. 'Ethnic Identities and Cultural Capital: An Ethnography of Chinese Opera in Singapore.' Identities: Global Studies in Culture and Power 13: 283-307.

Crane, Diana 2002. 'Culture and Globalization: Theoretical Models and Emerging Trends.' Pp. 1-25 in Global Culture: Media, Arts, Policy, and Globalization, edited by Diana Crane, Nobuko Kawashima and Ken'ichi Kawasaki. New York, NY: Routledge.

Crane, Diana, Nobuko Kawashima and Kenichi Kawasaki 2002. Global Culture: Media, Arts, Policy, and Globalization. New York, NY: Routledge.

Delanty, Gerard 2003. 'Consumption, Modernity and Japanese Cultural Identity: The Limits of Americanization.' Pp. 114-33 in Global America? The Cultural Consequences of Globalization, edited by Ulrich Beck, Natan Sznaider and Rainer Winter. Liverpool, UK: Liverpool University Press.

Fernandes, Sujatha 2006. Cuba Represent! Cuban Arts, State Power, and the Making of New Revolutionary Cultures. Durham, NC: Duke University Press.

Friedman, Jonathan 1990. 'Being in the World: Globalization and Localization.' Pp. 311-28 in Global Culture: Nationalistm, Globalization and Modernity, edited by Mike Featherstone. London: Sage Publications.

Friedman, Jonathan 2006. 'Culture and Global Systems.' Theory, Culture \& Society 23: 404-6.

Giddens, Anthony 1990. The Consequences of Modernity. Stanford, CA: Stanford University Press.

Hannerz, Ulf 1990. 'Cosmopolitans and Locals in World Culture.' Pp. 237-51 in Global Culture: Nationalism, Globalization and Modernity, edited by Mike Featherstone. Newbury Park, CA: Sage Publications.

Held, David, Anthony Mcgrew, David Goldblatt and Jonathan Perraton 1999. Global Transformations: Politics, Economics and Culture. Stanford, CA: Stanford University Press.

Huntington, Samuel 1993. 'The Clash of Civilizations.' Foreign Affairs 72: 22-50.

Iwabuchi, Koichi 2002. 'From Western Gaze to Global Gaze: Japanese Cultural Presence in Asia.' Pp. 256-73 in Global Culture: Media, Arts, Policy, and Globalization, edited by Diana Crane, Nobuko Kawashima and Ken'ichi Kawasaki. New York, NY: Routledge.

Kaplan, Richard L. 2002. 'Blackface in Italy: cultural power among nations in the era of globalization.' Pp. 191-211 in Global Culture: Meida, Arts, Policy, and Globalization, edited by Diana Crane, Nobuko Kawashima and Ken'ichi Kawasaki. New York, NY: Routledge.

Liebes, Tamar and Elihu Katz 1993. The Export of Meaning: Cross-cultural Readings of Dallas. Cambridge, UK: Polity Press.

Meyer, John W., John Boli, George M. Thomas and Francisco O. Ramirez 1997. 'World Society and the Nation-State.' American Journal of Sociology 103: 144-82.

Regev, Motti 1997. 'Rock Aesthetics and Musics of the World.' Theory, Culture \& Society 14: $125-42$.

Regev, Motti 2003. "'Rockization”: Diversity within Similarity in World Popular Music.' Pp. 222-34 in Global America? The Cultural Consequences of Globalization, edited by Ulrich Beck, Natan Sznaider and Rainer Winter. Liverpool, UK: Liverpool University Press.

Ritzer, George 2007. The Globalization of Nothing 2. Thousand Oaks, CA: Pine Forge Press.

Ritzer, George and Todd Stillman 2003. 'Assessing McDonaldization, Americanization and Globalization.' Pp. 30-48 in Global America? The Cultural Consequences of Globalization, edited by Ulrich Beck, Natan Sznaider and Rainer Winter. Liverpool, UK: Liverpool University Press.

Robertson, Roland 1992. Globalization: Social Theory and Global Culture. London: Sage.

Robertson, Roland 1995. 'Glocalization: Time-Space and Homogeneity-Heterogeneity.' Pp. 25-44 in Global Modernities, edited by Mike Featherstone, Scott Lash and Roland Robertson. London: Sage Publications.

Robertson, Roland 1997. 'Social Theory, Cultural Relativity and the Problem of Globality.' Pp. 69-90 in Culture, Globalization and the World-System: Contemporary Conditions for the Representation of Identity, edited by Anthony D. King. Minneapolis, MN: University of Minnesota Press. 
Sklair, Leslie 1995. Sociology of the Global System. Baltimore, MD: The Johns Hopkins University Press.

Smith, Anthony 1990. 'Towards a Global Culture?' Pp. 171-91 in Global Culture: Nationalistm, Globalization and Modernity, edited by Mike Featherstone. London: Sage Publications.

Stokes, Martin 2004. 'Music and the Global Order.' Annual Review of Anthropology 33: 47-72.

Tomlinson, John 1991. Cultural Imperialism: A Critical Introduction. Baltimore, MD: Johns Hopkins University Press.

Tomlinson, John 1999. Globalization and Culture. Chicago, IL: University of Chicago Press. 